\title{
Characterization of Xanthomonas citri pv. glycines Population Genetics and Virulence in a National Survey of Bacterial Pustule Disease in Korea
}

\author{
In-Jeong Kang ${ }^{1,2 *}$, Kyung Seok Kim ${ }^{3}$, Gwyn A. Beattie ${ }^{4}$, Hyunjung Chung ${ }^{1}$, Sunggi Heu ${ }^{5}$, and Ingyu Hwang ${ }^{2}$ \\ ${ }^{1}$ Division of Crop Cultivation and Environment Research, National Institute of Crop Science, Suwon 16613, Korea \\ ${ }^{2}$ Department of Agricultural Biotechnology, Seoul National University, Seoul 08826, Korea \\ ${ }^{3}$ Department of Natural Resource Ecology and Management, Iowa State University, Ames, IA 50011, USA \\ ${ }^{4}$ Department of Plant Pathology and Microbiology, Iowa State University, Ames, IA 50011, USA \\ ${ }^{5}$ Department of Plant Science, Seoul National University, Seoul 08826, Korea
}

(Received on November 4, 2021; Revised on November 16, 2021; Accepted on November 16, 2021)

Xanthomonas citri pv. glycines $(\mathrm{Xcg})$ is a major pathogen of soybean (Glycine max) in South Korea, despite the availability of soybean varieties with some resistance. We conducted a nationwide survey of the incidence and severity of bacterial pustule caused by Xcg. The percentage of infected fields was $7 \%$ to $17 \%$ between 2015 and 2017 . We characterized the diversity of a nationwide collection of $106 \mathrm{Xcg}$ isolates based on avrBs3 banding patterns. The isolates fell into 11 groups, each represented by a type strain; only two of these were similar to isolates collected from 1999 to 2002. The diversity of $\mathrm{Xcg}$ strains increased and the dominant strains changed between 1999 and 2017, with three new type strains comprising $44 \%$ of the isolates examined in 2012 to 2017. Pathogenicity tests did not show evidence for a shift in the races or aggressiveness of $\mathrm{Xcg}$ strains. Korean soybean cultivars, including the widely-grown Daewon cultivar, were susceptible to the 11 new type strains. The cultivar CNS, which carries the $\operatorname{rxp}$ resistance gene, was susceptible to most type strains, including two representing $83 \%$ of the Korean Xcg strains. In contrast, Williams 82, which also carries $\operatorname{rxp}$, showed resistance to at least five type strains.

*Corresponding author.

Phone) +82-31-695-0653, FAX) +82-31-695-0635

E-mail) fairjung@korea.kr

Handling Editor : Youn-Sig Kwak

(c) This is an Open Access article distributed under the terms of the Creative Commons Attribution Non-Commercial License (http:// creativecommons.org/licenses/by-nc/4.0) which permits unrestricted noncommercial use, distribution, and reproduction in any medium, provided the original work is properly cited.

Articles can be freely viewed online at www.ppjonline.org.
Collectively, these results suggest that Williams 82 has resistance loci in addition to $\operatorname{rxp}$. The widespread distribution of $\mathrm{Xcg}$, the high virulence of the current endemic strains, and the low resistance of most Korean soybean cultivars collectively favor widespread disease in Korea in years that are favorable to pustule development.

Keywords : new race, pathogenicity, soybean, Xanthomonas citri pv. glycines

Bacterial pustule caused by Xanthomonas citri pv. glycines (Xcg), previously classified as X. axonopodis pv. glycines (Constantin et al., 2016), is an important disease of soybean and has been reported in most soybean-growing areas of the world (Hartman et al., 2016). The effect of bacterial pustule on the growth and development of soybean largely depends on infection levels, with high infection levels decreasing yields by $20 \%$ to $60 \%$ following natural or artificial infection (Hokawat and Rudolph, 1991; Hong et al., 2011; Shukla, 1994). In Korea, bacterial pustule is one of the most common bacterial diseases of soybean. It occurs nationwide and can be observed any time from July to September. A survey of the distribution of bacterial pustule in Korea in 1997 and 1998 found the disease in 85 of 99 fields examined (Lee, 1999), including in fields in the provinces of Gyeonggi, Gangwon, Chungbuk, Chungnam, Jeonbuk, and Gyeongbuk. A similar level of disease incidence, $89.7 \%$, was observed in a survey conducted in 2005 and 2006 in the southern regions of Korea (Hong et al., 2010). Here we provide an updated nationwide survey on the occurrence and severity of bacterial pustule in Korea; this was last examined in 1998 (Lee, 1999). 
Although bactericides such as copper can be used to control bacterial pustule, bactericides are expensive as a management tool for a field crop and risk enriching for resistant populations of the pathogen and other non-target bacteria. Soybean varieties that are resistant to bacterial pustule are known and have been used to effectively manage this disease. However, only one gene, $\operatorname{rxp}$ (resistance to xanthomonas phaseoli), is currently known to confer resistance in soybean, and this resistance is only partial (Bernard and Weiss, 1973). The rxp gene was originally found as a recessive resistance gene in the cultivar CNS (Hartwig and Lehman, 1951). This gene has been introduced into many commercial soybean cultivars, including the popular cultivars Williams and Williams 82 that were developed by the United States Department of Agriculture (Hartwig and Lehman, 1951; Narvel et al., 2001). The $\operatorname{rxp}$ gene has not yet been cloned, and the availability of bacterial pustuleresistant commercial varieties is still limited. To date, the incorporation of $\operatorname{rxp}$ into Korean soybean cultivars has not been reported, and the $X c g$ avirulence gene that triggers rxp-mediated resistance has not been identified.

The successful deployment of resistant soybean varieties in a geographical region requires knowledge of the population genetics of the pathogen in that region. Strains of the bacterial pustule pathogen have been shown to fall into distinct races (Athinuwat et al., 2009; Hwang and Lim, 1998; Park et al., 2008) and to differ in their aggressiveness (Kaewnum et al., 2005). Hwang and Lim (1998) examined the ability of $63 \mathrm{Xcg}$ isolates to induce disease on a set of 11 differential soybean cultivars, including Chippewa, Harosoy, Mukden, Pella, and Williams, and on this basis classified the isolates into five races, designated 1,2, 3, 4, and 5 . The molecular basis of this race specificity, including the identity of potential bacterial effectors interacting with resistance genes, is not yet known. Similarly, Kaewnum et al. (2005) demonstrated that $26 \mathrm{Xcg}$ isolates from Thailand differ in their aggressiveness in inducing disease on soybean cultivars and in their ability to induce a hypersensitive response on a range of plant species, including tobacco, cucumber, pea, and sesame. Similar to the previous study, the $X c g$ genes that influence differential aggressiveness on these cultivars are not known. Lastly, Park et al. (2008) classified $155 \mathrm{Xcg}$ isolates from Korea into at least six groups based on the number and size of the genomic fragments hybridizing with an avrBs 3 family gene probe; such differences in avrBs 3 content could be correlated with resistance and/or aggressiveness. This work identified six type strains that represent these groups. Collectively, these studies highlight natural variation among $X c g$ strains that could underly population and/or genetic shifts that impact the successful use of soybean varieties resistant to bacterial pustule.

Although commercial soybean varieties with at least partial resistance to bacterial pustule have been developed for other areas of the world, this disease remains a problem for soybean cultivation in Korea. The objectives of this study were (1) to survey the current distribution of bacterial pustule throughout Korea, (2) to evaluate if new groups of $X c g$ isolates as defined by avrBs 3 profiles have emerged in Korea since the six type strains were identified in 2008, and (3) if new $a v r B s 3$ groups are identified, to evaluate if they represent new races of Korean $X c g$ isolates. This study is the first to characterize the diversity of Korean $X c g$ strains since 2008 and is intended to provide guidance in developing strategies to deploy soybean varieties resistant to bacterial pustule caused by $X c g$ in Korea.

\section{Materials and Methods}

Survey of disease occurrence. Disease surveys were conducted in 2015, 2016, and 2017 to estimate the incidence and severity of bacterial pustule in soybean fields throughout the Republic of Korea. Fields were selected in at least three regions in each of eight provinces; the regions chosen were those with the greatest area of cultivated soybeans in each of the provinces. Selected fields had soybeans grown in an area over $1,000 \mathrm{~m}^{2}$. Fields were surveyed once from August to September during each year of the survey. Each field was assessed for the presence of bacterial pustule disease, with a field designated as infected if even one symptomatic plant was observed. For each infected field, the infection rate of bacterial pustule was estimated as the percentage of the total number of plants that exhibited bacterial pustule symptoms. The mean infection rate across all of the fields in a region across all survey dates was determined. For each infected field, the disease severity was estimated as the percentage of the total leaf surface area that was covered with bacterial pustule symptoms. Our methods for estimating disease incidence and severity were in accordance with the Agricultural Science and Technology Research and Analysis Standards of the Rural Development Administration (Rural Development Administration, 2012).

Isolate collection and identification. To generate a collection of $X c g$ isolates, we collected leaves exhibiting bacterial pustule symptoms from every infected field. Excised pustule-containing leaf tissues were surface sterilized with $1 \%$ hypochlorite for $90 \mathrm{~s}$, rinsed once in sterile water, and then macerated with $1 \mathrm{ml}$ of sterile water. The suspension 
was streaked onto a tryptic soy agar (TSA) medium, and colonies with the characteristic morphology of $\mathrm{Xcg}$ were selected for isolation. To identify the bacterial pustule pathogens, putative $X c g$ isolates were identified based on the sequences of the 16S ribosomal RNA (rRNA) gene, DNA gyrase subunit B gene $(g y r B)$ and the RNA polymerase beta subunit gene $(r p o B)$; the primers are shown in Supplementary Table 1 . In addition, the isolates were evaluated using the GEN III MicroPlate system (Biolog Inc., Hayward, CA, USA). In short, the isolates were grown for $48 \mathrm{~h}$ at $30^{\circ} \mathrm{C}$ under aerobic conditions on Biolog Universal growth medium without blood. The identity of the isolates was determined using the manufacturer's instructions with inoculating fluid A, incubation for $24 \mathrm{~h}$ at $25^{\circ} \mathrm{C}$, and $\mathrm{Om}-$ niLog MicroArray Data Collection Software 1.2. Isolates that were verified to be $X c g$ were cultured in tryptic soy broth (TSB) with shaking at $28^{\circ} \mathrm{C}$ for $24 \mathrm{~h}$ and preserved in $20 \%$ glycerol (v/v) at $-72^{\circ} \mathrm{C}$.

Isolation of genomic DNA and Southern blot analysis of avrBs3 repeats. To extract genomic DNA, Xcg cells grown on TSA medium were subcultured into TSB medium (casein peptone $17 \mathrm{~g}$, soya peptone $3 \mathrm{~g}$, sodium chloride $5 \mathrm{~g}$, dipotassium hydrogen phosphate $2.5 \mathrm{~g}$, glucose $2.5 \mathrm{~g}$ in 1 liter distilled water) in a $28^{\circ} \mathrm{C}$ shaking incubator for $24 \mathrm{~h}$. Bacterial DNA was extracted from $1 \mathrm{ml}$ of cells grown to an optical density at $600 \mathrm{~nm}\left(\mathrm{OD}_{600}\right)$ of 0.8 to 1.0 using a commercial genomic DNA extraction kit (iNtRON Biotechnology, Inc., Seongnam, Korea) and the protocol for Gram-negative bacteria. The concentration of extracted DNA was estimated using a spectrophotometer (BioDrop Duo, Biochrom Ltd., Cambridge, UK).

For Southern blot analysis, genomic DNA of Xcg was digested with the restriction enzyme Bam HI (New England Biolabs, Ipswich, MA, USA). Electrophoretic separation and transfer to nylon membranes were performed as described (Sambrook et al., 1989). For DNA hybridization, a digoxigenin (DIG)-labeled avrBs3 gene probe was used; this probe was comprised of a $3.3-\mathrm{kb}$ internal BamHI fragment of avrBs3 cloned into pBlueScript, as described previously (Park et al., 2008), using a commercial protocol for DIG-labeled probes and membrane hybridization (Roche Diagnostics, Mortsel, Belgium). Detection of hybridization was performed using an anti-DIG antibody (Roche Diagnostics) and subsequent exposure to an X-ray film (Agfa CP-BU new).

Assay for resistance to bacterial pustule disease. Seeds of soybean (Glycine max L.) of American and Korean varieties were obtained from the Korean Agricultural Culture
Collection at the RDA in Korea. Plants were grown in the greenhouse to vegetative stage 3 . $X c g$ strains were grown on TSA for 2 days at $28^{\circ} \mathrm{C}$, then colonies were suspended in sterilized $10 \mathrm{mM} \mathrm{MgCl}$ and adjusted to an $\mathrm{OD}_{600}$ of 0.5 , which corresponded to a cell density of $\sim 5 \times 10^{8} \mathrm{cfu} /$ $\mathrm{ml}$. Bacterial suspensions were inoculated into the fully expanded two leaves by spraying with an air compressor (SMH10L, SMASH, China) with a $2.5-\mathrm{kPa}$ injection pressure. All plant inoculation experiments were repeated 3 times, and each replicate consisted of three plants. Disease was assessed at 7 days post-inoculation. Disease severity was assessed on three leaflets per plant using a disease severity index that was scored, on a per leaflet basis, as 0 for no pustules, 1 for 1-25 pustules, 2 for $26-50$ pustules, 3 for 51-75 pustules, 4 for 76-100 pustules, and 5 for $>100$ pustules. To provide a conservative estimate of resistance, we reported the average of the two highest severity indices scored.

Assay for induction of the hypersensitive response. Isolates were tested for their ability to induce a hypersensitive response (HR) on four species of tobacco (Nicotiana rustica L., Nicotiana benthamiana L., Nicotiana tabacum L. cv. Xanthi and Nicotiana tabacum L. cv. Samsun), pepper (Capsicum annuum L. cv. Supermanita), sesame (Sesamum indicum L. cv. Milsung), and tomato (Solanum lycopersicum M. cv. Berry King F). Inocula of Xcg strains were prepared as described above for the resistance assay, but were adjusted to an $\mathrm{OD}_{600}$ of $0.3\left(\sim 5 \times 10^{7} \mathrm{cfu} / \mathrm{ml}\right)$. Bacterial suspensions were infiltrated into the leaf mesophyll using a 1-ml hypodermic syringe without a needle. Infiltrated zones were observed for development of tissue collapse and cell death within $24 \mathrm{~h}$ post-infiltration. A negative response was indicated by some yellowing but no visible collapse or cell death in the infiltrated zone, whereas a positive response was indicated by complete collapse and cell death in the infiltrated area.

\section{Results and Discussion}

Recent trends in the disease incidence and severity of bacterial pustule in Korea. A nationwide survey of the incidence and severity of bacterial pustule caused by $X c \mathrm{~g}$ was conducted from 2015 to 2017. Bacterial pustule was observed widely across Korea (Table 1). Nationwide, the incidence of bacterial pustule was similar in 2015 and 2016, but increased in 2017 (Table 2). In particular, the percentage of fields nationwide that were infected increased from $7 \%$ to $8 \%$ in 2015 and 2016, respectively, to over $17 \%$ in 2017 , thus the number of fields with bacterial 
Table 1. Bacterial pustule incidence and severity in three annual surveys in Korea

\begin{tabular}{|c|c|c|c|c|c|c|c|c|c|c|c|c|c|}
\hline \multirow[b]{2}{*}{ Province } & \multirow[b]{2}{*}{ Region } & \multicolumn{4}{|c|}{2015} & \multicolumn{4}{|c|}{2016} & \multicolumn{4}{|c|}{2017} \\
\hline & & $\begin{array}{l}\text { No. of } \\
\text { fields }\end{array}$ & $\begin{array}{l}\text { No. of } \\
\text { infected } \\
\text { fields }^{\mathrm{a}}\end{array}$ & $\begin{array}{l}\text { Infection } \\
\text { rate }^{\mathrm{b}}(\%)\end{array}$ & & $\begin{array}{l}\text { No. of } \\
\text { fields }\end{array}$ & $\begin{array}{l}\text { No. of } \\
\text { infected } \\
\text { fields }\end{array}$ & $\begin{array}{l}\text { Infection } \\
\text { rate }(\%)\end{array}$ & Severity & $\begin{array}{l}\text { No. of } \\
\text { fields }\end{array}$ & $\begin{array}{c}\text { No. of } \\
\text { infected } \\
\text { fields }\end{array}$ & $\begin{array}{l}\text { Infection } \\
\text { rate }(\%)\end{array}$ & Severity \\
\hline \multirow[t]{4}{*}{ Gyeonggi } & Yeoncheon & 15 & 0 & - & - & 15 & 1 & 10 & + & 15 & 1 & 10 & + \\
\hline & Suwon & 12 & 0 & - & - & 5 & 0 & - & - & 15 & 4 & 10 & +++ \\
\hline & Paju & 10 & 0 & - & - & 10 & 0 & - & - & 15 & 2 & 30 & ++ \\
\hline & Pocheon & 0 & - & - & - & 10 & 0 & - & - & 7 & 0 & - & - \\
\hline \multirow[t]{5}{*}{ Gangwon } & Yeongwol & 15 & 2 & 10 & ++ & 15 & 0 & - & - & 15 & 2 & 10 & +++ \\
\hline & Pyeongchang & 17 & 2 & 10 & ++ & 17 & 0 & - & - & 15 & 0 & - & - \\
\hline & Hoengseong & 5 & 0 & - & - & 0 & - & - & - & 0 & - & - & - \\
\hline & Inje & 10 & 1 & 10 & + & 0 & - & - & - & 0 & - & - & - \\
\hline & Jeongseon & 0 & - & - & - & 5 & 1 & 10 & ++ & 5 & 1 & 10 & ++ \\
\hline \multirow[t]{4}{*}{ Chungbuk } & Goesan & 10 & 4 & 50 & ++++ & 10 & 0 & - & - & 15 & 2 & 10 & ++ \\
\hline & Danyang & 20 & 2 & 10 & + & 20 & 0 & - & - & 10 & 0 & - & - \\
\hline & Jecheon & 30 & 1 & 10 & ++ & 20 & 1 & 10 & + & 10 & 3 & 10 & ++ \\
\hline & Chungju & 3 & 3 & 10 & ++ & 3 & 1 & 10 & ++ & 5 & 1 & 10 & ++ \\
\hline \multirow[t]{5}{*}{ Chungnam } & Seosan & 10 & 2 & 15 & ++ & 8 & 1 & 10 & ++ & 10 & 2 & 10 & ++ \\
\hline & Taean & 20 & 0 & - & - & 15 & 1 & 10 & + & 20 & 3 & 10 & +++ \\
\hline & Gongju & 20 & 0 & - & - & 10 & 2 & 10 & + & 15 & 3 & 10 & ++ \\
\hline & Hongseong & 0 & - & - & - & 3 & 0 & - & - & 10 & 0 & - & - \\
\hline & Cheongyang & 10 & 0 & - & - & 4 & 1 & 10 & ++ & 10 & 3 & 10 & ++ \\
\hline \multirow[t]{4}{*}{ Jeonbuk } & Gimje & 10 & 0 & - & - & 12 & 1 & 10 & ++ & 20 & 6 & 15 & +++ \\
\hline & Sunchang & 10 & 1 & 10 & + & 10 & 2 & 10 & ++ & 20 & 4 & 10 & +++ \\
\hline & Gochang & 10 & 0 & - & - & 10 & 2 & 10 & ++ & 10 & 3 & 10 & ++ \\
\hline & Jeongeup & 0 & - & - & - & 0 & - & - & - & 10 & 2 & 10 & ++ \\
\hline \multirow[t]{3}{*}{ Jeonnam } & Jangheung & 5 & 2 & 25 & ++ & 0 & - & - & - & 10 & 3 & 10 & +++ \\
\hline & Muan & 58 & 4 & 10 & ++ & 25 & 3 & 30 & ++++ & 25 & 8 & 30 & ++ \\
\hline & Hampyung & 0 & - & - & - & 10 & 1 & 10 & ++ & 0 & - & - & - \\
\hline \multirow[t]{7}{*}{ Gyeongbuk } & Andong & 20 & 1 & 10 & ++++ & 15 & 1 & 10 & ++ & 20 & 2 & 10 & ++ \\
\hline & Cheongdo & 10 & 1 & 10 & ++ & 0 & - & - & - & 0 & - & - & - \\
\hline & Chilgok & 6 & 0 & - & - & 0 & - & - & - & 0 & - & - & - \\
\hline & Gyeongsan & 5 & 0 & - & - & 0 & - & - & - & 0 & - & - & - \\
\hline & Mungyung & 0 & - & - & - & 15 & 1 & 30 & ++++ & 25 & 3 & 30 & ++++ \\
\hline & Sangju & 0 & - & - & - & 5 & 0 & - & - & 8 & 0 & - & - \\
\hline & Yecheon & 10 & 0 & - & - & 10 & 1 & 10 & ++ & 10 & 2 & 10 & ++ \\
\hline \multirow[t]{3}{*}{ Gyeongnam } & Hapcheon & 10 & 0 & - & - & 7 & 1 & 20 & +++ & 7 & 1 & 10 & ++ \\
\hline & Geochang & 5 & 0 & - & - & 15 & 1 & 20 & ++++ & 8 & 1 & 10 & ++ \\
\hline & Changyeong & 6 & 0 & - & - & 5 & 1 & 20 & +++ & 1 & 1 & 10 & ++ \\
\hline
\end{tabular}

${ }^{\mathrm{a}}$ Number of fields examined, and number of infected fields.

${ }^{\mathrm{b}}$ Infection rate is the average infection rate (\% of plants infected) in infected fields in a region.

${ }^{\mathrm{c}}$ Severity reflects the average percentage of leaf area that was symptomatic in infected fields in a region, where + is $1-10 \%,++$ is $11-30 \%,+++$ is $30-50 \%$, and $+1++$ is $>50 \%$.

pustule doubled in 2017. Whereas the percentage of fields with bacterial pustule increased in Korea in 2017, the average within-field infection rate per region did not (Table 2). The average disease severity in those fields that were infected increased slightly (Table 2). Increased incidence of bacterial pustule was also observed when the percentage of infected fields was examined on a per-province basis (Table 3). The average within-field infection rate did not parallel the increased percentage of fields with bacterial pustule when examined on a per-province basis, and the 
Table 2. Summary of annual survey data of bacterial pustule in Korea

\begin{tabular}{lccc}
\hline Parameter & 2015 & 2016 & 3017 \\
\hline Total no. of fields examined & 372 & 309 & 372 \\
Disease incidence & & & 24 \\
$\quad$ Total no. of infected fields in Korea & 26 & 7.8 & 17.0 \\
$\quad$ of infected fields in Korea & 7.0 & $13.7 \pm 1.6$ & $12.7 \pm 1.4$ \\
$\quad$ Within-field infection rate per region & \\
Disease severity $^{\text {Within-field disease index per region }}{ }^{\mathrm{a}}$ & $12.7 \pm 3.0$ & & $2.2 \pm 0.2$ \\
\hline
\end{tabular}

${ }^{a}$ The mean within-field infection rate and mean within-field disease index per region were determined only for fields with disease. Data shown are the mean \pm standard error of the mean. The mean within-field disease index was calculated by converting the severity data shown in Table 1 to numerical scores of 1 to 4 , where 1 represents + and 4 represents ++++ .

Table 3. Summary of annual survey data of bacterial pustule in Korea by province ${ }^{\mathrm{a}}$

\begin{tabular}{|c|c|c|c|c|c|c|c|c|c|c|c|c|}
\hline \multirow{2}{*}{ Province } & \multicolumn{3}{|c|}{ No. of fields } & \multicolumn{3}{|c|}{ Infected fields (\%) } & \multicolumn{3}{|c|}{ Within-field infection rate $(\%)$} & \multicolumn{3}{|c|}{ Severity } \\
\hline & 2015 & 2016 & 2017 & 2015 & 2016 & 2017 & 2015 & 2016 & 2017 & 2015 & 2016 & 2017 \\
\hline Gyeonggi & 37 & 40 & 52 & - & 2.5 & 13.5 & - & 10 & 17 & - & 1.0 & 2.0 \\
\hline Gangwon & 47 & 37 & 35 & 10.6 & 2.7 & 8.6 & 10 & 10 & 10 & 1.7 & 2.0 & 2.5 \\
\hline Chungbuk & 63 & 53 & 40 & 15.9 & 3.8 & 15.0 & 20 & 10 & 10 & 2.3 & 1.5 & 2.0 \\
\hline Chungnam & 60 & 40 & 65 & 3.3 & 12.5 & 16.9 & 15 & 10 & 10 & 2 & 1.5 & 2.3 \\
\hline Jeonbuk & 30 & 32 & 60 & 3.3 & 15.6 & 25 & 10 & 10 & 11 & 1.0 & 2.0 & 2.5 \\
\hline Jeonnam & 63 & 35 & 35 & 9.5 & 11.4 & 31.4 & 18 & 20 & 20 & 2.0 & 3.0 & 2.5 \\
\hline Gyeongbuk & 51 & 45 & 63 & 3.9 & 6.7 & 11.1 & 10 & 17 & 17 & 3.0 & 2.7 & 2.7 \\
\hline Gyeongnam & 21 & 27 & 22 & - & 11.1 & 13.6 & - & 20 & 10 & - & 3.3 & 2.0 \\
\hline Means & 46.5 & 38.6 & 46.5 & 5.8 & 8.3 & 16.9 & 13.8 & 13.3 & 13.1 & 2.0 & 2.1 & 2.3 \\
\hline$\pm \mathrm{SE}$ & \pm 5.6 & \pm 2.8 & \pm 5.6 & - & - & - & - & - & - & \pm 0.3 & \pm 0.3 & \pm 0.1 \\
\hline
\end{tabular}

${ }^{a}$ Data shown are the sum of the total no. of fields, the percentage of the total number of fields that were infected, and the within-field infection rate and severity for those fields showing disease, where the latter were calculated by converting the severity data shown in Table 1 to numerical scores of 1 to 4 , where 1 represents + and 4 represents ++++ .

severity increased slightly (Table 3 ). Among the provinces, Gyeonggi was notable for the dramatic increase in bacterial pustule in 2017, having had almost no bacterial pustule detected in the nearly 40 fields examined in 2015 and 2016 (Table 1). Nationwide, however, the endemic nature of bacterial pustule was demonstrated by the detection of the disease every year of the survey in $27 \%$ of the regions that were surveyed in all three years.

The increase in disease incidence in 2017 could be due to climatic factors, shifts in the pathogen populations in Korea, shifts in soybean varieties used, and a combination of these or other factors. Bacterial pustule is generally favored by high temperatures and frequent precipitation (Bradbury, 1984; Hartman et al., 2016; Moffett and Croft, 1983). Bacterial pustule in Korea can be observed from July when the plants are in vegetative stages to September when the plants have passed flowering, with disease severity often correlated with the amount of precipitation in August (Hong et al., 2011). Weather data collected in 2015, 2016, and
2017 indicate that precipitation across Korea in August of 2017 was much higher than in August of 2015 and 2016, with $241 \mathrm{~mm}$ of total precipitation in 2017 versus only 111.3 and $76.2 \mathrm{~mm}$ in 2015 and 2016, respectively (https:// data.kma.go.kr/cmmn/main.do). Thus, conditions conducive to disease are likely to be one factor contributing to the high incidence of disease in 2017. Below, we explore the possibility of population shifts in the Xcg pathogen.

Xcg strain diversity based on profiles of avrBs3 repeats in the genome. Strains of $X c g$ have been found to carry multiple genes encoding homologs of the AvrBs3 effector family (Kim et al., 2006; Park et al., 2008). Effectors in this family are transcription activator-like effectors that are secreted by the bacterial type III secretion system and influence the expression of host genes involved in disease resistance or susceptibility (Hueck, 1998). The presence of multiple copies of this gene family in Xcg may be due to their association with plasmids and mobile genetic ele- 
Table 4. Type strains of the Xanthomonas citri pv. glycines isolates obtained in this study ${ }^{\mathrm{a}}$

\begin{tabular}{lccl}
\hline Strain name & No. of $a v r B s 3$ repeats & Isolates $(\%)$ & \multicolumn{1}{c}{ Origin } \\
\hline K1 & 7 & 0.9 & Goesan-gun, Chungcheongbuk-do, isolated in 2017 \\
K10 & 6 & 35 & Taean-gun, Chungcheongnam-do, isolated in 2017 \\
K13 & 4 & 0.9 & Jangheung-gun, Jeollanam-do, isolated in 2017 \\
K20 & 5 & 0.9 & Cheongyang-gun, Chungcheongnam-do, isolated in 2016 \\
K29 & 5 & 48 & Jecheon-si, Chungcheongbuk-do, isolated in 2015 \\
K34 & 5 & 3.8 & Goesan-gun, Chungcheongbuk-do, isolated in 2015 \\
K46 & 4 & 0.9 & Pyeongchang-gun, Gangwon-do, isolated in 2015 \\
K47 & 4 & 4.7 & Seosan-si, Chungcheongnam-do, isolated in 2015 \\
K53 & 5 & 1.9 & Inje-gun, Gangwon-do, isolated in 2015 \\
K79 & 6 & 0.9 & Sacheon-si, Gyeongsangnam-do, isolated in 2013 \\
K100 $^{c}$ & 6 & 1.9 & Cheongyang-gun, Chungcheongnam-do, isolated in 2016 \\
\hline
\end{tabular}

${ }^{\mathrm{a}} \mathrm{All}$ of the strains were pathogenic on soybean.

${ }^{\mathrm{b}}$ Type strain K29 is the same as type strain OcsF (Park et al., 2008).

'Type strain K100 is the same as type strain SL1017 (Park et al., 2008).

ments (Kim et al., 2006). The presence of multiple copies enables strain profiling based on the size and number of genomic fragments that contain a copy of an avrBs 3 allele. To investigate whether the diversity of the $X c g$ strains in soybean cultivation fields in Korea have changed since isolates collected in 1999 to 2002 were examined (Park et al., 2008), we characterized total $106 \mathrm{Xcg}$ strains including the strains isolated from $>150$ bacterial pustule leaf lesions collected during our nationwide survey from 2015 to 2017 (Supplementary Table 2). These isolates were confirmed to be $X c g$ strains using Biolog data (Supplementary Fig. 1) and phylogenetic analyses based on $16 \mathrm{~S}$ rRNA, gyrB, and

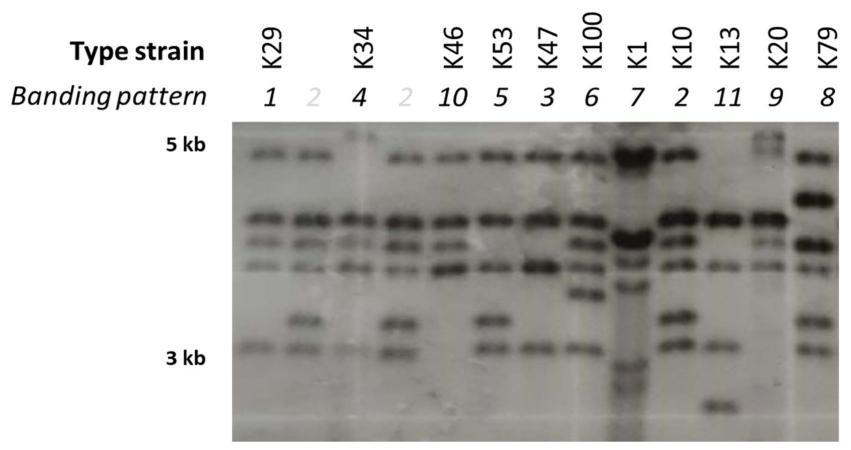

Fig. 1. Southern blot analysis of $X$. citri pv. glycines strains isolated in Korea from 2012 to 2017. Genomic DNA was digested by BamHI, run on a gel, hybridized with the pBSavrXa10 to probe for $a v r B s 3$, and detected using X-ray film. DNA ladder with sizes labeled on the left (in $\mathrm{kb}$ ). Distinct banding patterns are labeled with numbers above the lanes, and those corresponding to the designated type strains are labeled with the strain names. Bands that are particularly dense reflect $a v r B s 3$ alleles that putatively are on plasmids (Park et al., 2008).
rроB gene sequences (Supplementary Fig. 2). In contrast to Park et al. (2008) who identified six Xcg groups based on $a v r B s 3$ banding patterns, we found that the 106 strains examined fell into 11 groups (Fig. 1). We selected strains from each group to serve as type strains (Table 4, Fig. 1). Only two of these groups, K29 and K100, had a similar avrBs 3 banding pattern to previously identified groups (Table 4).

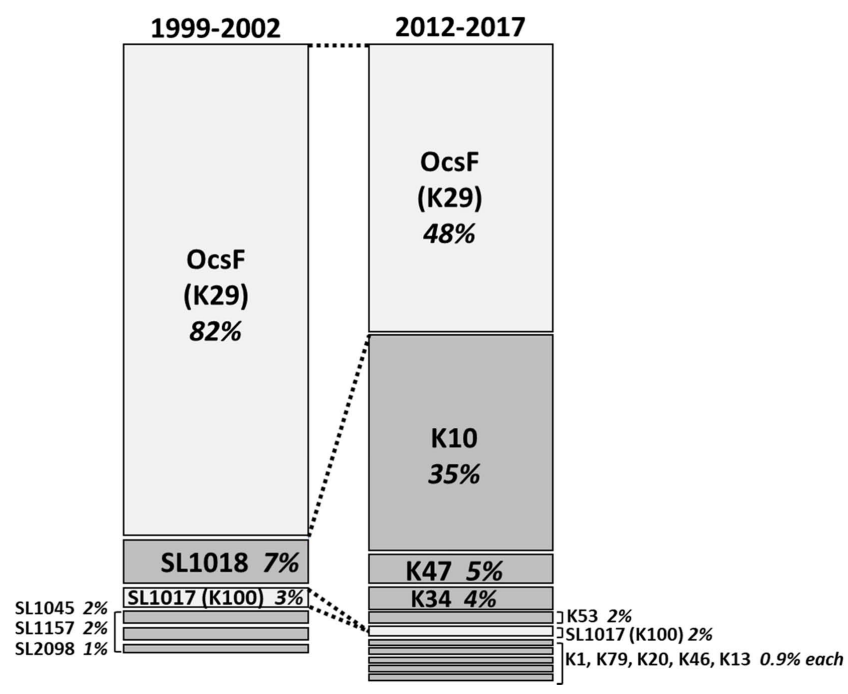

Fig. 2. Shift in the relative abundance of Xanthomonas citri pv. glycines $(X c g)$ strain groups in Korea over a 13- to 15-year period. The strain groups were identified on the basis of their avrBs 3 banding pattern among 155 isolates collected in 1999 to 2002 (Park et al., 2008) and 106 isolates collected in 2012 to 2017 (this study). Two groups exhibited similar banding patterns in the two surveys: the groups labeled OcsF and SL1017, as labeled by Park et al. (2008), which corresponded to the groups labeled K29 and $\mathrm{K} 100$, respectively, in this study. 
In addition to an increase in the number of strain groups identified between 1999-2002 and 2012-2017, we identified a major shift in the relative abundance of these strain groups (Fig. 2). The K29 group exhibited the same avrBs3 banding pattern as the previously identified OcsF group (Park et al., 2008). In both survey periods, strains with this banding pattern were predominant among the Xcg isolates; however, the proportion of these isolates decreased from over $80 \%$ in $1999-2002$ to $48 \%$ in 2012-2017 (Table 4, Fig. 2). The K100 group also exhibited the same avrBs 3 banding pattern as a previous group, the SL1017 group, but this group was present at a low relative abundance, $\leq 3 \%$, in both survey periods. Notably, a new strain group, designated K10, emerged as a second predominant group in 2012-2017; this group comprised 35\% of the isolates in the most recent survey and was not identified in the isolates collected in 1999-2002. Three new type strains, K10, K47, and $\mathrm{K} 34$, collectively comprised $44 \%$ of the isolates examined, demonstrating a major shift in the pathogen population over about a two-decade period. The K10 group may have been present at a low frequency in the earlier survey period. Whether it was present in that period or emerged in the intervening years, the high abundance of this strain group indicates that it was favored by the soybean genotypes, cultivation conditions, and/or climactic conditions in Korea.

Responses of soybean cultivars to the $\mathrm{Xcg}$ type strains. $X c g$ strains have been divided into races based on their ability to induce disease in a panel of five differential cultivars (Williams, Harosoy, Pella, Chippewa, and Mukden) (Hwang and Lim, 1998). The Korean Xcg type strains isolated from 1999 to 2002 were screened on these five cultivars and 14 Korean soybean cultivars, and some resistance to these strains was identified in both sets of cultivars (Park et al., 2008). Here, the $X c g$ type strains isolated from 2012 to 2017 were screened on a similar set of cultivars to evaluate if shifts have occurred in Korean $X c g$ populations in the last decades. The response of 21 soybean cultivars to the 11 type strains resulted in a higher disease index across all cultivars and strains (mean of 3.8) than was observed in the study by Park et al. (2008) (mean of 2.3) (Table 5), suggesting that the strains were generally more virulent or the conditions were more conducive to disease during this

Table 5. Bacterial pustule disease severity induced by the type strains of Xanthomonas citri pv. glycines $^{\mathrm{a}}$

\begin{tabular}{lccccccccccc}
\hline & K1 & K10 & K13 & K20 & K29 & K34 & K46 & K47 & K53 & K79 & K100 \\
\hline Soybean cultivars used globally & & & & & & & & & & & \\
Chippewa & 4.0 & 5.0 & 4.0 & 3.5 & 4.5 & 5.0 & 4.5 & 5.0 & 5.0 & 4.0 & 5.0 \\
CNS & 4.0 & 4.0 & 3.5 & 3.0 & 3.5 & 4.5 & 4.0 & 4.5 & 4.0 & 3.5 & 4.5 \\
Harosoy & 4.0 & 4.0 & 4.0 & 3.0 & 4.5 & 4.0 & 4.0 & 4.5 & 4.0 & 3.5 & 5.0 \\
Mukden & 4.0 & 5.0 & 4.0 & 4.5 & 4.5 & 5.0 & 5.0 & 5.0 & 5.0 & 4.0 & 5.0 \\
Peking & 4.0 & 4.5 & 4.0 & 4.5 & 4.0 & 5.0 & 5.0 & 5.0 & 5.0 & 4.0 & 5.0 \\
Pella & 4.0 & 3.5 & 4.0 & 4.0 & 4.5 & 4.0 & 4.5 & 4.5 & 5.0 & 4.0 & 5.0 \\
Williams & 2.0 & 3.0 & 2.0 & 1.0 & 2.0 & 3.5 & 3.0 & 3.5 & 3.0 & 4.0 & 3.0 \\
Williams 82 & 2.0 & 1.0 & 1.0 & 1.0 & 1.0 & 2.5 & 3.5 & 3.5 & 3.5 & 3.0 & 3.5 \\
Soybean cultivars used in Korea & & & & & & & & & & & \\
Daepung2 & 4.0 & 3.0 & 3.5 & 2.5 & 3.5 & 4.0 & 4.5 & 5.0 & 3.5 & 4.0 & 3.5 \\
Danbaek & 2.5 & 3.0 & 1.0 & 2.5 & 2.5 & 3.5 & 3.0 & 4.0 & 2.5 & 3.0 & 2.5 \\
Dawon & 4.5 & 5.0 & 4.0 & 4.0 & 4.0 & 5.0 & 4.5 & 4.0 & 5.0 & 2.5 & 5.0 \\
Gwangan & 3.0 & 2.5 & 3.0 & 4.0 & 2.5 & 4.0 & 4.0 & 4.0 & 3.5 & 2.0 & 4.5 \\
Hannam & 4.0 & 4.0 & 4.0 & 4.0 & 4.0 & 4.5 & 4.5 & 5.0 & 4.5 & 4.0 & 4.5 \\
Manri & 5.0 & 5.0 & 4.0 & 4.0 & 4.0 & 5.0 & 4.0 & 5.0 & 5.0 & 3.5 & 4.5 \\
Moohan & 4.5 & 5.0 & 3.5 & 4.0 & 3.5 & 4.0 & 4.0 & 4.0 & 3.0 & 3.5 & 3.0 \\
Pungsannamul & 2.0 & 2.0 & 2.5 & 1.0 & 2.0 & 3.0 & 2.5 & 3.5 & 3.5 & 2.0 & 3.0 \\
Pureun & 3.0 & 4.0 & 3.5 & 2.5 & 2.5 & 3.5 & 3.5 & 4.0 & 4.0 & 3.5 & 4.0 \\
Sinpaldal2 & 3.0 & 3.5 & 1.0 & 2.0 & 3.0 & 3.0 & 3.0 & 2.0 & 3.5 & 2.0 & 5.0 \\
Somyung & 3.0 & 2.0 & 3.5 & 2.0 & 3.0 & 3.0 & 3.5 & 3.5 & 3.5 & 3.5 & 3.5 \\
Daewon & 4.5 & 5.0 & 4.5 & 5.0 & 5.0 & 5.0 & 4.5 & 4.5 & 4.5 & 4.5 & 4.5 \\
Taekwang & 4.5 & 5.0 & 5.0 & 5.0 & 5.0 & 5.0 & 4.5 & 5.0 & 4.5 & 4.0 & 4.5 \\
\hline
\end{tabular}

${ }^{a}$ Disease severity was evaluated on a 0 to 5 scale, with 0 indicating no pustules and 5 representing $>100$ pustules per leaflet.

${ }^{\mathrm{b}}$ Cultivars Williams 82, Williams, and CNS are known to carry the rxp resistance gene. 


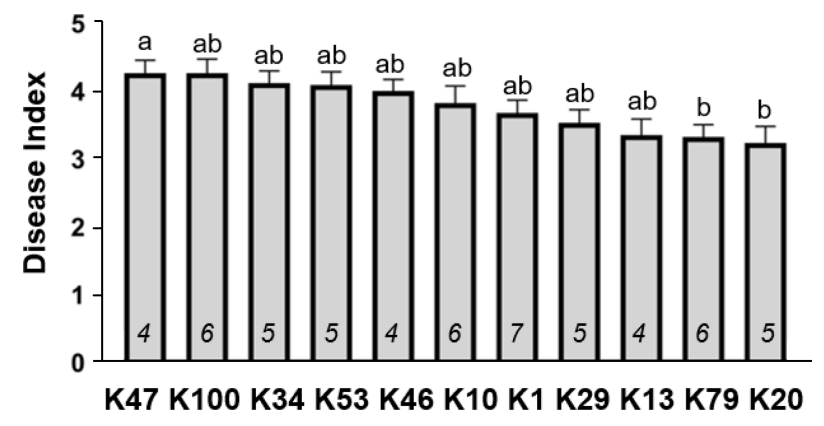

Fig. 3. Variation in the aggressiveness of the $X c g$ type strains in inducing bacterial pustule on soybean. The average disease index across 17 soybean cultivars tested (data were excluded for cultivars Williams and Williams 82) is shown for the 11 type strains. Italicized numbers within the bars are the $a v r B s 3$ family copy number. Values shown are the mean \pm standard error of the mean, with significant differences based on analysis of variance and a Kruskal-Wallis multiple comparison test $(P<0.1)$.

recent screen.

The cultivars Williams 82 and Williams that carry the rxp resistance gene showed the most resistance to the most strains (Table 5). With the exception of type strain K79 on Williams, the disease indices on these cultivars were in the bottom quartile of the disease indices (i.e., $\leq 3.5$ ) for all cultivar $\mathrm{x}$ type strain combinations screened. However, some strains were moderately virulent on Williams (K47, K79) and Williams 82 (K46, K47, K53, and K100) (Fig. 3). Although Hwang and Lim (1998) identified a Xcg strain with virulence to Williams, this is the first report of $X c g$ strains showing virulence to Williams 82. Cultivar CNS also carries the $\operatorname{rxp}$ gene, but this cultivar exhibited less resistance than Williams or Williams 82 to all of the type strains except K79. Park et al. (2008) found that cultivars with the rxp gene were resistant to the type strain that represented the majority (83\%) of the Korean Xcg strains from 1999 to 2002, suggesting that $\operatorname{rxp}$ could be useful if deployed for resistance in Korean soybean cultivars, although the causal nature of $\operatorname{rxp}$ to resistance to these strains is not known. Interestingly, we found that CNS (PI 548445), which carries rxp, was susceptible to the two type strains that represented the majority (84\%) of the Korean Xcg strains, K29 and $\mathrm{K} 10$, as well as to most of the other type strains, whereas Williams 82 and Williams, which also have rxp, were resistance to at least five Korean strains, indicating that two cultivars might have resistance loci in addition to $\operatorname{rxp}$.

The Xcg strains in this study could not be classified into races based on their profile of virulence to the five cultivars used in previous studies (Chippewa, Harosoy, Mukden, Pella, and Williams) (Hwang and Lim, 1998). Although Williams showed some variation in resistance to the new
Korean type strains, the cultivars Chippewa, Harosoy, Mukden, Pella and also Peking were highly susceptible to all of the new Korean type strains. Similarly, the Xcg type strains did not exhibit notable differences in aggressiveness on these cultivars, as the disease indices were almost all $\geq$ 4.0.

The Korean cultivars were, in general, also highly susceptible to the $11 \mathrm{Xcg}$ type strains (Table 5), including the cultivar Daewon, which is widely grown in Korea. However, several cultivars exhibited a differential response to distinct type strains. The highest levels of resistance were Danbaek and Sinpaldal2 to strain K13, and Pungsannamul to strain K20. The next highest levels of resistance were observed in only four cultivars, Gwangan to strain K79, Pungsannamul to strains K1, K10, K29 and K79, Sinpaldal2 to strains K20, K47 and K79, and Somyung to strains $\mathrm{K} 10$ and $\mathrm{K} 20$. If these resistance responses reflect cultivar-specific recognition of avirulence genes in the type strains, then cultivars Pungsannamul and Sinpaldal2 and type strains K10, K20, and K79 are the best candidates for future studies exploring these host-specific interactions. In the absence of effector-triggered resistance, the variation in disease indices among the cultivars (Fig. 3) may reflect variation in the aggressiveness of the strains on the cultivars tested. Consistent with the findings of Park et al. (2008), we did not find evidence that the copy number of the $a v r B s 3$ family genes influenced $X c g$ aggressiveness on these soybean cultivars (Fig. 3).

Responses of nonhost plant species to the $X c g$ type strains. In a previous study, Kaewnum et al. (2005) demonstrated that $26 \mathrm{Xcg}$ isolates from Thailand demonstrated not only variability in aggressiveness in their pathogenicity on soybean, but also variability in their ability to induce HR on nonhost plant species. Here, we evaluated the ability of the $11 \mathrm{Xcg}$ type strains to induce the HR on diverse nonhost plant species. We did not observe variation among the $X c g$ type strains, as none of them induced a HR on two species of Nicotiana or on two cultivars of tobacco $(N$. tabacum L.). Similarly, none of them induced an HR on pepper (Capsicum annuum L.) or sesame (Sesame indicum L.), and they all induced an HR on tomato (S. lycopersicum M.). In previous studies, a U.S. strain of $X c g$, strain 8ra, similarly failed to induce HR on tobacco and induced it on tomato, but strain 8ra also induced HR on pepper, unlike all of the type strains in this study. Our findings support the ability of $\mathrm{Xcg}$ strains to induce an HR in a plant-specific manner, although the basis for this specificity is not known, but they do not provide further evidence for genetic variation among $X c g$ strains in their ability to induce HR on any 
of the nonhost species examined.

Conclusions. In contrast to previous surveys of bacterial pustule in Korea that estimated that $86 \%$ of Korean soybean cultivation fields had bacterial pustule (Lee, 1999), we found only $7 \%$ to $8 \%$ of these fields were infected in 2015 and 2016. The recent survey varied from the previous ones in being nationwide and in surveying at least three times more fields. Despite this broadening of the survey, the factors responsible for the large decrease in bacterial pustule between 1997-1998 (Lee, 1999) and 2015 are not clear. The decrease could be related to a transition in the soybean cultivars that were planted. In the 1990s, the cultivars Taekwang and Daewon were the most widely grown cultivars in Korea, but since then, other varieties have displaced Taekwang. This decrease in disease could also be associated with shifts in the pathogen population toward reduced virulence or changes in climate. Given the favorability of high temperatures and heavy rainfall to bacterial pustule development, decreased disease would more likely be an outcome of water restriction and drought events in agricultural areas than warming temperatures (Lee and Shin, 2021). Our survey data also indicated that the incidence of bacterial pustule in Korea over doubled between 2016 and 2017. This increase could be due to similar factors, in this case, an increase in the precipitation in August of 2017, decreased use of resistant soybean cultivars and/or shifts toward increased virulence of the predominant $X c g$ strains.

Our data indicate that significant population shifts occurred in the $\mathrm{Xcg}$ strains in soybean cultivation fields in Korea between 1999-2002 and 2012-2017. The dominant strains changed, and the diversity of the populations increased based on the greater number of distinct type strains and the greater evenness in their relative abundance. Although the $X c g$ strains varied in their virulence on a set of 21 host cultivars, they generally exhibited strong virulence, and the Korean soybean cultivars exhibited little resistance to these strains. Collectively, these data do not support the possibility that shifts in the $\mathrm{Xcg}$ population contributed to the decreased incidence in bacterial pustule in Korea in the last decade. However, they predict that in years that are favorable to pustule development, the widespread distribution of the pathogen, the high virulence of the current endemic strains, and the low resistance of the Korean soybean cultivars are likely to create opportunities for widespread disease. Consequently, continued efforts to identify and integrate genetic resistance into commercial cultivars for soybean cultivation in Korea are important, but based on the susceptibility of CNS to all of the $X c g$ type strains representing the $\mathrm{Xcg}$ populations across Korea, this genetic resistance should target resistance beyond that mediated by rxp.

\section{Conflicts of Interest}

No potential conflict of interest relevant to this article was reported.

\section{Acknowledgments}

This research was co-funded by research grants from the Cooperative Research Program for Ag-riculture Science \& Technology Development of the Rural Development Administration in the Republic of Korea (Project title: Identification of distribution and pathogenic variation in isolates of Xanthomonas citri pv. glycines), grant number PJ01357303; the Next-Generation BioGreen 21 Program of the Rural Development Administration in the Republic of Korea (Project title: Development of a platform for breeding of disease resistance in soybean: Bacterial leaf pustule and Phytophthora root rot); grant number PJ01574401.

\section{Electronic Supplementary Material}

Supplementary materials are available at The Plant Pathology Journal website (http://www.ppjonline.org/).

\section{References}

Athinuwat, D., Prathuangwong, S., Cursino, L. and Burr, T. 2009. Xanthomonas axonopodis pv. glycines soybean cultivar virulence specificity is determined by avrBs3 homolog avrXgl. Phytopathology 99:996-1004.

Bernard, R. L. and Weiss, M. G. 1973. Qualitative genetics. In: Soybeans: improvement, production, and uses, ed. by B. E. Caldwell, pp. 117-164. American Society of Agronomy, Madison, WI, USA.

Bradbury, J. F. 1984. Genus II. Xanthomonas Dowson 1939, 187. In: Bergey's manual of systematic bacteriology, Vol. 1, eds. by N. R. Krieg and J. G. Holt, pp. 199-210. Williams \& Wilkins, Baltimore, MD, USA.

Constantin, E. C., Cleenwerck, I., Maes, M., Baeyen, S., Van Malderghem, C., De Vos, P. and Cottyn, B. 2016. Genetic characterization of strains named as Xanthomonas axonopodis pv. dieffenbachiae leads to a taxonomic revision of the $X$. axonopodis species complex. Plant Pathol. 65:792-806.

Hartman, G. L., Rupe, J. C., Sikora, E. J., Domier, L. L., Davis, J. A. and Steffey, K. L. 2016. Compendium of soybean diseases and pests. 5th ed. American Phytopathological Society, St. Paul, MN, USA.

Hartwig, E. E. and Lehman, S. G. 1951. Inheritance of resistance to bacterial pustule disease in soybeans. Agron. J. 43:226- 
229.

Hokawat, S. and Rudolph, K. 1991. Variation in pathogenicity and virulence of strains of Xanthomonas campestris pv. glycines, the incitant of bacterial pustule of soybean. J. Phytopathol. 131:73-83.

Hong, S.-J., Kim, Y.-K., Jee, H.-J., Lee, B.-C., Yoon, Y.-N. and Park, S.-T. 2010. Selection of bactericides for controlling soybean bacterial pustule. Res. Plant Dis. 16:266-273 (in Korean).

Hong, S.-J., Kim, Y.-K., Jee, H.-J., Shim, C.-K., Kim, M.-J., Park, J.-H., Han, E.-J. and Lee, B.-C. 2011. Influence of disease severity of bacterial pustule caused by Xanthomonas axonopodis pv. glycines on soybean yield. Res. Plant Dis. 17:317-325 (in Korean).

Hueck, C. J. 1998. Type III protein secretion systems in bacterial pathogens of animals and plants. Microbiol. Mol. Biol. Rev. 62:379-433.

Hwang, I. and Lim, S. M. 1998. Pathogenic variability in isolates of Xanthomonas campestris pv. glycines. Korean J. Plant Pathol. 14:19-22.

Kaewnum, S., Prathuangwong, S. and Burr, T. J. 2005. Aggressiveness of Xanthomonas axonopodis pv. glycines isolates to soybean and hypersensitivity responses by other plants. Plant Pathol. 54:409-415.

Kim, J.-G., Choi, S., Oh, J., Moon, J. S. and Hwang, I. 2006. Comparative analysis of three indigenous plasmids from Xanthomonas axonopodis pv. glycines. Plasmid 56:79-87.

Lee, J. and Shin, H. 2021. Assessment of future climate change impact on an agricultural reservoir in South Korea. Water 13:2125.

Lee, S. D. 1999. Occurrence and characterization of major plant bacterial diseases in Korea. Ph.D. thesis. Seoul National University, Seoul, Korea.

Moffett, M. L. and Croft, B. J. 1983. Xanthomonas. In: Plant bacterial diseases: a diagnostic guide, eds. by P. C. Fahy and G. J. Persley, pp. 189-228. Academic Press, New York, NY, USA.

Narvel, J. M., Jakkula, L. R., Phillips, D. V., Wang, T., Lee, S.-H. and Boerma, H. R. 2001. Molecular mapping of Rxp conditioning reaction to bacterial pustule in soybean. J. Hered. 92:267-270.

Park, H.-J., Han, S.-W., Oh, C., Lee, S., Ra, D., Lee, S.-H. and Heu, S. 2008. Avirulence gene diversity of Xanthomonas axonopodis pv. glycines isolated in Korea. J. Microbiol. Biotechnol. 18:1500-1509.

Rural Development Administration. 2012. The agricultural science and technology research and analysis standards. 5th ed. Rural Development Administration, Suwon, Korea. 424 pp.

Sambrook, J., Fritsch, E. F. and Maniatis, T. 1989. Molecular cloning: a laboratory manual. 2nd ed. Cold Spring Harbor Laboratory Press, Cold Spring Harbor, NY, USA. 1546 pp.

Shukla, A. K. 1994. Pilot estimation studies of soybean (Glycine max) yield losses by various levels of bacterial pustule (Xanthomonas campestris pv. glycines) infection. Int. J. Pest Manage. 40:249-251. 